Article

\title{
Dirty Banking: Probing the Gap in Sustainable Finance
}

\author{
Michael A. Urban * and Dariusz Wójcik
}

School of Geography and the Environment, Oxford University Centre for the Environment, University of Oxford, South Parks Road, Oxford OX1 3Q, UK; dariusz.wojcik@spc.ox.ac.uk

* Correspondence: michael.urban@ouce.ox.ac.uk; Tel.: +44-(0)7817-166860

Received: 24 December 2018; Accepted: 25 February 2019; Published: 22 March 2019

\begin{abstract}
In 2016, the Global Sustainable Investment Alliance estimated the market for sustainable investments to have reached 22.89 trillion USD of assets under management. While financial institutions have embraced the idea of sustainable finance as a business opportunity, they have arguably done little, but to piggy-back on investors' demand. Today, it is not unusual for a single firm to retail fossil free investment funds and concomitantly offer commercial loans towards fracking, coal, and Arctic drilling. This paradox is underpinned by a major gap in the way sustainability has permeated primary and secondary markets which, we argue, calls for a serious rethinking of the sustainability transition in finance. This article proposes two contributions in this direction. First, we develop an original conceptualisation of finance as a socio-technical system to discuss the dynamics that both hinder and promote a transition from mainstream to sustainable finance. Second, we propose to study how investment banks integrate sustainability in their underwriting services. To do so, we filter through close to half a million of debt and equity underwriting deals (2005-2017) using the Government Pension Fund Global of Norway's list of 153 excluded companies. Our results suggest that investment banks do not shy away from underwriting companies that have been flagged for major environmental, social, and governance misconduct, neither do they restrain from underwriting companies providing contentious products, such as tobacco, coal, and nuclear weapons. Moving forward, we suggest ways to address this problem and call for further research on the responsibility and agency of finance and advanced business services firms in sustainability transitions.
\end{abstract}

Keywords: sustainable finance; primary markets; investment banking

\section{Introduction}

Investment banks connect issuers of debt and equity securities with investors [1]. Investment bank syndicates function as centralized agents that promote and guarantee the transmission of newly issued securities from issuers to asset managers. As such, they provide a crucial transactional function in capital markets. They have considerable informational advantages, including access to insider information about their clients, as well as a privileged network of sizable investors and other investment banks participating in syndication. Although individual banks would have the capability to underwrite deals on their own, they prefer syndication in order to pool investor networks and improve the pricing of newly issued securities [2,3]. Every year, investment banks help corporations and governments raise trillions of USD of new finance in global capital markets. Therefore, they constitute a powerful segment of the financial industry [4].

According to Scholtens, "Finance is grease to the economy. As such, it can also affect the sustainability and social responsibility of the firm" [5]. Given their informational advantages, investment banks are in a unique position to evaluate the environmental, social, and governance performance of their clients and could be instrumental agents in pushing for higher standards. Despite 
their fundamental importance in promoting a transition towards a more sustainable form of economic development, the underwriting activities of investment banks have, to this day, received little to no attention from sustainable finance scholars. This paper addresses this gap. In light of systematic empirical evidence, we show that investment banks provide underwriting services to companies that have and /or will, to a high degree of certainty, cause environmental, social, and governance harm. Although banks do develop corporate social responsibility (CSR) programs [6-9] and contribute to philanthropic activities $[10,11]$, our results suggest that underwriting is a banking activity that has entirely missed the sustainability transition in finance.

Hereafter, we define sustainable finance in the spirit of the Brundtland Commission (1987) - that is, finance that protects the fundamental right of "all human beings" to "an environment adequate for their health and well-being" and safeguards inter-generational equity [12]. We further use the environmental, social, and governance (ESG) nomenclature to refer to specific dimensions of sustainable finance when needed.

Traces of sustainable finance date back to at least the 16th century [13]. However, developments only really accelerated in the second half of the 20th century [14]. While finance-led activism predominantly stemmed from civil society and rallied ethically motivated investors $[15,16]$, its founding principles have gradually permeated mainstream finance. During the 1970s, while Milton Friedman was notoriously arguing that the sole responsibility of the firm is to make a profit for its shareholders [17], a serious scientific debate on whether corporate social and environmental responsibility translates into better profits picked up steam $[18,19]$. Overall, the evidence collected over the last 50 years suggests that superior ESG performance on material issues (issues deemed strategically relevant to corporate context [6]) is good for business (for detailed literature reviews on the topic see $[20,21])$. This scientific and business-minded approach to sustainability has had a profound impact on the expansion of sustainable finance.

Today, sustainable finance is a booming market segment dominated by profit-seeking firms. The United Nations Principles for Responsible Investments (UN PRI), a prominent non-profit and non-governmental organisation in sustainable investment worldwide, has over 1800 signatories, including leading financial institutions, such as BlackRock, the Vanguard Group, and Goldman Sachs Asset Management. In 2016, the Global Sustainable Investment Alliance estimated the market for sustainable investment strategies to have reached 22.89 trillion of USD of assets under management [22]. While numbers suggest a significant shift in mentality, the growth of the market for sustainable finance has been met with a fair share of criticism.

Richardson noted that the wide-spread adoption of sustainable finance by mainstream financial institutions has come at the cost of a significant loss in ethical substance [23]. In his seminal review entitled Finance as a Driver of Corporate Social Responsibility, Scholtens further highlighted the lack of engagement with sustainable finance by institutions active in primary markets [5]. Indeed, sustainable finance initiatives of incumbents tend to piggy-back on investors' demand and largely focus on secondary markets. Instead of tackling the problem at the source-by promoting the issuance of new debt and equity finance that meets sustainable development goals—-the sustainability transition in finance has largely consisted of a taxonomic exercise that aims at labelling old finance (debt and equity finance already emitted and exchanged on secondary markets) under various declinations of sustainability (socially and/or environmentally responsible, green, ethical, etc.) designed to match a variety of investors' preferences. Although we acknowledge the merits of such advances, we contend with Scholtens that the sustainability transition in finance and beyond requires sustainable development goals to be embedded in the negotiation of new rather than old finance.

In this article, we show systematic evidence of an alarming lack of integration of the most basic principles underpinning sustainable development goals in investment banks' underwriting services. Given the central function investment banks occupy in the creation and circulation of new debt and equity finance, our findings call for an urgent engagement from both scholars and practitioners concerned with the promotion of sustainable development. 
The article is organised as follow: In Section 2, we review key developments pertaining to primary markets in sustainable finance. While the evidence we present is by no means exhaustive, it shows that while the financial sector may be accelerating towards a sustainability transition, it does so in an extremely selective and fragmented way. In Section 3, we propose to make sense of this fragmentation by proposing an original theoretical framework to conceptualise the sustainability transition in finance. This system-wide theoretical elaboration sets the stage to tackle a fundamentally important missing link: Sustainable investment banking. In Section 4, we propose to study investment banks' treatment of unsustainable corporations in the provision of underwriting services. To do so, we analyse close to half a million of investment banking underwriting deals over the period of 2005 and 2017 to flag deals that have and/or will, to a high degree of certainty, cause environmental, social, and governance harm. In Section 5, we discuss limitations, propose pathways towards sustainable investment banking, and conclude with research implications for scholarship in sustainable finance.

\section{Sustainable Finance: Fragmented Developments}

While sustainable finance remains underdeveloped, the diversity and scope of private sector, government, non-governmental, and non-profit innovations of the last 50 years is impressive. While providing an exhaustive overview of the state of the art in sustainable finance is beyond the scope of this article, we review key initiatives and institutions in an effort to sketch the contours of the field. Building on Scholtens' critique, we pay particular attention to developments affecting primary markets [5]. Indeed, Scholtens observed that, although bank lending remained the largest source of net financing for non-financial enterprises, sustainable bank lending was still crucially undertheorized by scholars and under-developed by practitioners. While his critique still holds a decade later, grassroots developments suggest that important reforms are underway.

The World Bank has announced that from 2019 it will stop lending to firms involved in oil and gas extraction, just as it stopped financing coal-fired power stations in 2010. Prominent private sector financial institutions are also increasingly taking a stance on climate change with new financing policies. European banks, such as Societe Generale, HSBC, and Credit Agricole, have recently pledged to stop financing companies operating coal power-plants and coal mines. BNP Paribas has committed to stop lending to companies involved with tar sands, fracking, and Arctic drilling [24] while Deutsche Bank has promised to put a halt to new credit lines for coal companies [25]. Interestingly, notwithstanding the importance of these commitments, they indirectly demonstrate the unwillingness of the sector to develop and implement comprehensive ESG policies. For the handful of companies taking a strategic stance on cherry-picked issues, thousands remain silent and complacent.

Generally, the financial sector seems to place an emphasis on strategically riding investors' preferences rather than advancing best practices. Institutional investors (pension funds in particular) are increasingly demanding that their assets be invested in a manner consistent with long-term sustainable development goals. This explains why sustainability is markedly more developed in secondary markets. Meanwhile, according to a report by a consortium of environmental pressure groups, between 2015 and 2017, the "extreme fossil fuels sector" received a total of 345 billion USD in bank loans from leading financial institutions, with no signs of this activity contracting [26]. The Royal Bank of Canada (RBC) - the second largest extreme fossil fuel lender after China Construction Bank-provided just short of $8 \%$ of that total. Paradoxically, in 2017, RBC launched an investment fund named "RBC Vision Fossil Fuel Free Global Equity Fund". Such contradictions are legion among banks.

Overall, mainstream financial institutions still fall short of putting their money where their mouth is. Although scholarship is advancing new conceptualization to promote the integration of sustainability principles into global supply chains [27], banks still struggle to develop and implement them consistently across the products and services they offer. Arguably, the development of ethical banking is a direct symptom of this failure. Indeed, the existence of ethical banking implies that mainstream banking remains problematic enough to call for an alternative proposition. The fact that ethical banking currently stands as a niche "counter-movement" is a testament to its limited 
scale and subversive nature [28]. Ethical banks operate at the margin of mainstream finance to serve neglected markets. While there are examples of profitable ethical banks, they usually generate much smaller revenues and profit margins than mainstream banks. Ethical banks have a markedly different network compared to mainstream banking institutions. In particular, they have strong connections with civil society and nurture strong relationships with clients that distrust mainstream financial institutions $[13,28]$.

The European bank, Triodos, is a prime example. Founded in the 1980s, Triodos first got involved with project financing in renewable energy, micro-credit, and fair-trade, and later moved into socially responsible investments (SRI) and retail banking. As a result of its alternative business model, it was not exposed to sub-prime assets in 2008-2009 and gained market shares in the Netherlands. Since ethical banking is a counter-movement rather than an industry-wide innovation in banking practices, it remains relatively small and highly specialized, and as such does not challenge the status quo. Kaufer stresses that compared to traditional banks, Triodos suffers from fewer opportunities for efficiency gains via standardization (due-diligence is much more labour intensive in ethical banking) and handles a slimmer and riskier project pipeline, which puts a strain on profitability [29].

One has to concede that it would be unfair, or at the very least simplistic, to only blame financial institutions for failing to meet sustainable development goals. Behind every unsustainable bank loan stands a complex web of economic and political interest groups, including powerful industrial lobbies and regulators. So far, most mainstream sustainable finance initiatives has been orchestrated by non-binding voluntary codes of conduct signed by many and rigorously observed by few. One major organism is the United Nations Environmental Program Financial Initiative (UNEP FI). In 2016, it regrouped 213 members from banking, insurance, and investment, spanning 60 countries, and accounting for a total of 62 trillion USD of assets. Since 1992, leading financial institutions have signed the UNEP FI's statement of commitment asserting that they “... openly recognize the role of the financial services sector in making our economy and lifestyles sustainable and commit to the integration of environmental and social considerations into all aspects of their operations". The fact that the Royal Bank of Canada-which lent 26.5 billion USD to extreme fossil fuels between 2015 and 2017-appears amongst the list of signatories suggests that behaviour lags behind intention.

Although these high-level initiatives provide important platforms for the exchange of ideas and best practices, they remain insufficient. In the absence of top-down regulatory initiatives to create a level playing field, the sustainability transition is bound to lag behind the problems it is trying to address. Whilst we recognise the significance of the decisions made by major financial institutions to stop financing the most contentious segments of the energy sector, such as coal, fracking, and Arctic drilling, it nevertheless resonates more as a token of good-will than real change. Here again, the findings we share in our empirical analysis underscore a problematic lack of cohesion. For instance, we show that in 2017 most, if not all, leading investment banks continued to underwrite the debt and equity of coal producers with gusto. Ten years later, we re-assert Scholtens' [5] concerns over the lack of engagement by the financial sector in promoting sustainable finance at the source and express doubts on the extent and the coherence of the sustainability transition in finance. Before presenting the results of our empirical analysis, we develop a theoretical framework to help make sense of these disjointed developments.

\section{Finance as a Socio-Technical System: Making Sense of the Sustainability Transition in Finance}

We propose to revisit Geels' multi-level perspective (MLP) to offer a framework on sustainable finance transition [30,31]. Doing so, we develop an original conceptualisation of finance as a socio-technical system and use it to discuss the dynamics that both hinder and promote a regime change from mainstream finance to sustainable finance. We acknowledge the framework's ontological limits $[32,33]$ as well as the growing theoretical normativity induced by its success in sustainability transition research [34]. Notwithstanding limitations, we make two contributions: First, we invite social scientists interested in finance, broadly defined, to rethink the financial sector as a complex evolutionary 
socio-technical system. Second, we offer an original perspective on the dynamics underpinning innovations in sustainable finance, their co-evolution, as well as their adoption by incumbent institutions. Our discussion contributes to the burgeoning research in sustainability transitions.

Over the last decade, the MLP has been applied to study transitions in a variety of socio-technical systems. Geels applied his framework to transportation to look at the transition from horse-drawn carriages to automobiles [31]. Wiskerke and Van der Ploeg studied the transition towards sustainable agriculture [35]. Smith also used an MLP approach to analyse sustainability transitions in organic food and eco-housing [36] while others have used it to analyse transitions towards renewable energy [37,38]. In a rather pessimistic account on the impact of the financial crisis on the latter, Geels himself suggested that finance ought to be "... disciplined and reoriented in green directions" [38] (p. 69). Whilst we concur, we believe the sustainability transition requires a more hands-on scholarly engagement with the world of finance. Indeed, although we find mentions of Geels' work in research related to finance (see, for instance, [39] on the role of finance in energy transitions), as well as a number of passing references to finance in sustainability transitions research (see, for instance, $[38,40]$ ), there is to this day no scholarship in transition studies dedicated to finance. To the best of our knowledge, we are the first to theorize finance as a socio-technical system.

According to Geels, socio-technical systems "consist of a cluster of elements, including technology, regulation, user practices and markets, cultural meaning, infrastructure, maintenance networks and supply networks" [31] (p. 446). The MLP theorizes transitions in socio-technical systems through a hierarchy of three inter-related levels: Socio-technical landscape, socio-technical regime, and niche innovations. We offer a schematic presentation of these three levels and their interplay in Figure 1. Originating from the sociology of technology, socio-technical systems are understood as a set of "tangible elements needed to fulfil societal functions" [31] (p. 449). They are maintained and reproduced by social groups and governed by a regime (understood as a set of rules). The financial sector's socio-technical function is to create and circulate money through products and services designed, in theory, to minimise transaction costs and optimise risk-return [41,42]. This function, intrinsic to the performance of capitalist economies, is shaped by cultural and political values, and rests on a large technical infrastructure.

(1)

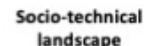

(3)

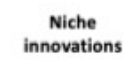

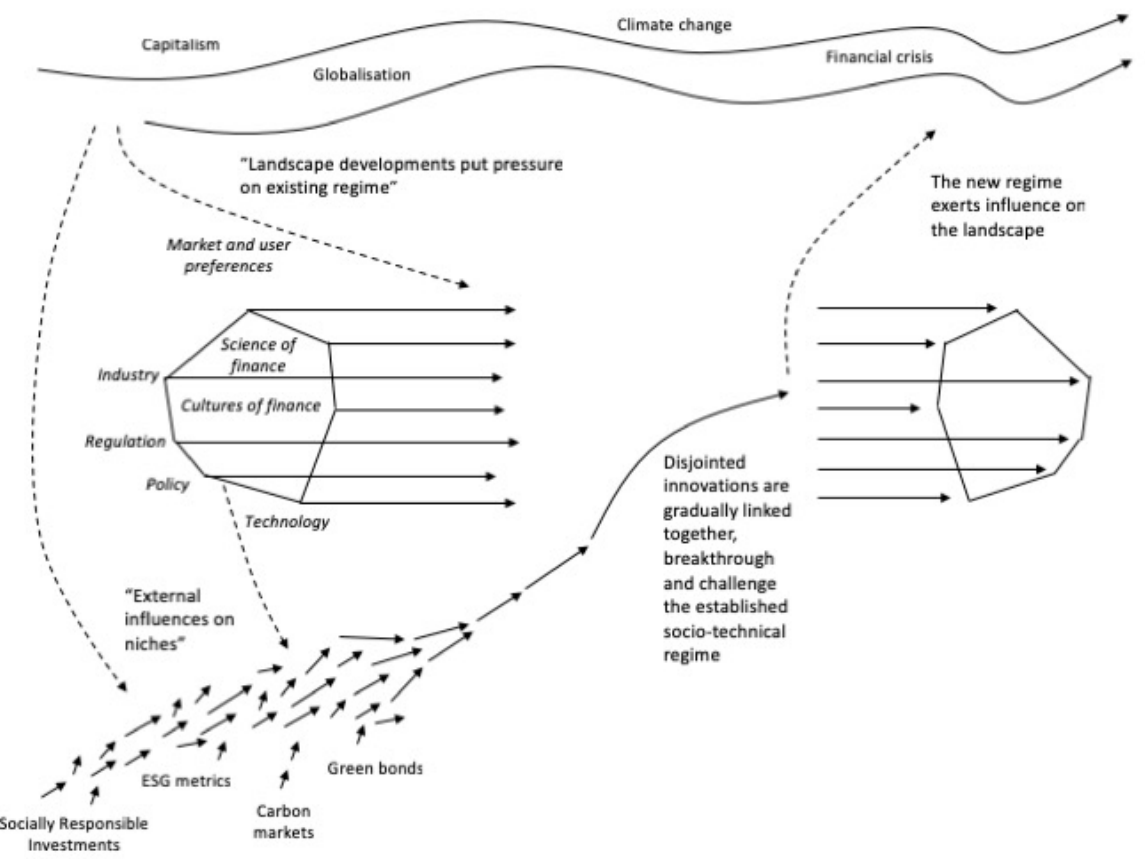

Figure 1. A multi-level perspective on finance. Source: authors, adapted from Geels, 2004, 2005. 
The financial sector operates within a socio-technical landscape (level 1 of Figure 1). According to Geels, the landscape entails "aspects of the wider exogenous environment that affect sociotechnical development" [31] (p. 451). It is a super-structure featuring a variety of social groups and institutions regulated by intersubjective norms and conventions. These norms and conventions result from economic, political, and social negotiations and struggles. Ideologically, the socio-technical landscape of finance is dominated by capitalism, which rests on private property and profit motives, and globalisation, which rests on the free flow of people, goods and services, ideas, financial capital, and information [43]. Capitalism and globalisation, as key tenants of the contemporary regime of finance, have a deep top-down influence on both the regime and the trajectory of niche innovations.

Landscape developments are discursive, non-linear, and involve multiple actors. They can, at times, compel changes in regimes by creating windows of opportunity for niche innovations to breakthrough. The recognition of key societal challenges, such as climate change, by leading political and economic institutions at the landscape level was fundamental to the development of grassroot sustainable finance innovations. The publication of Our common future in 1987 by the Brundtland Commission and the seminal definition of sustainable development it proposed was a major landscape development promoting sustainability transitions across socio-technical systems, including finance [44]. Equally important, the US withdrawal from the Paris Accord in 2017 was a major setback hindering decades of progress.

Financial crises, albeit created at a regime level, are often intertwined with landscape evolutions. As major financial crises morph into economic recessions, they create unemployment, bankruptcies, decrease personal income and corporate profits, and lead to decreases in tax revenues. These can in turn lead to austerity measures, leading to further socio-economic hardship. With regards to sustainability transitions, these landscape developments can put progressive as well as regressive pressure on incumbent regimes. For instance, whereas Perez argued that the 2008-2009 financial crisis was coincidentally intertwined with enough technological innovations to support a green golden age [45], Geels stressed that the crisis had put a strain on progress in renewable energy investment [38].

Beneath the landscape lies the socio-technical regime of finance, which, we argue, rests on seven interconnected pillars that shape and sustain it (level 2 of Figure 1). These seven pillars include: The industry of finance; market, and user preferences; the science of finance; the cultures of finance; technology; regulation; and policy. The industry of finance is composed by a complex web of actors, including central banks, insurance companies, commercial and retail banks, investment banks, stock exchanges as well as institutional investors, such as pension funds. Together these actors offer products and services that facilitate the core socio-technical function of the system-the creation and circulation of money. Investment banks help corporations find investors when they issue new equity and debt capital. Stock, commodity, and derivative exchanges help improve price formation by centralising transaction data, and pension funds provide risk-sharing and economies of scale to safeguard retirement security-we merely describe idealised functions and acknowledge the myriad of problematic socio-economic inefficiencies found across each one of these institutions.

The products and services offered by this complex global web of actors are shaped by demand factors. Market and user preferences typically entail attributes, such as transaction costs, investment liquidity, and risks, as well as reputation, trust, and sustainability. Changes in market and user preferences are intertwined with landscape developments and the supply of niche innovations. Financial transactions are further regulated by a normative body of knowledge we call the "science of finance" [46]. For over four decades, it has been dominated by neoclassical finance, which assumes utility maximisation, frictionless markets, and rational behaviour [47]. Notable models include the modern portfolio theory (MPT) and the capital asset pricing model (CAPM), both developed in the mid 20th century. These models, continuously adapted and improved upon, still largely shape capital market investments. While subject to incremental internal changes, the science of finance is at times challenged by scientific innovations. For instance, neoclassical finance and the efficient market hypothesis (EMH) have been challenged by behavioural finance [48], which emphasises the importance 
of irrationality and imperfect information in price formation [49]. Typically, ethical investors who seek to maximise sustainability over investment returns are market participants better understood by behavioural than neoclassical finance.

There is also a cultural dimension to finance. As Knox-Hayes emphasises, this is best understood as a variegated construct, constituted by, and functioning within, social institutions, and as such situated in space and time [50]. While there clearly are dominant spaces and institutions of finance, praxis conserves a degree of cultural localism. For instance, Hall and Appleyard argue that local business and finance education institutions "... territorially and societally embed financiers into particular regulatory regimes and organizational cultures" [51] (p. 597). To be sure, while we recognize the Anglo-Americanization of global finance led by New York and London-the dominant axis of contemporary finance [52]—we also see important spaces of differentiation in financial cultures.

Islamic financial services provide a good example. Bassens and Derudder, who explored the distinct trajectory of globalisation in the Gulf region, state: "Economic globalisation has not resulted in a simple implementation of Western business ethics, but is increasingly mediated through Islamic culture" [53] (p. 38). In short, there is no single culture of finance, but multiple cultures of finance. In 2016, while SRI were estimated to have overtaken non-SRI investments in Europe (53\% market share), they still claimed less than $1 \%$ of investments in Asia (ex-Japan) [22]. This is unsurprising considering that China, the economic powerhouse of the region, has traditionally subscribed to the idea that it is not the role of business to become involved in affairs considered part of the realm of the state-something Westermann-Behaylo calls "the separation thesis" [16]. Along with spatial differentiation, the cultures of finance are subject to renegotiations as social values and practices change over time. Their evolution is intertwined with broader transformations in the scientific, social, and political makeup of culture at a landscape level.

Another intrinsically important pillar of finance is regulation. Financial regulation is intertwined with broader landscape and regime level policies [54]. For instance, the near failure of major financial institutions during the 2008-2009 crisis has prompted significant regulatory efforts. Fixes aimed at containing the risks exposed by previous lax standards included the creation of a list of global systemically important banks (G-SIBs) by the Financial Stability Board, new bank capital requirements (Basel III) as well as a new framework designed to better protect investors (Markets in Financial Instruments Directive II-MiFID II). For all the efforts put on reengineering regulatory frameworks to support financial stability, financial sustainability is still to make its appearance on regulatory agendas. Although soft-law initiatives are plenty-the UN PRI, the Equator Principles (EP), the Task Force on Climate-Related Financial Disclosures (TCFD) as well as the Sustainable Development Goals (SDGs), to name a few-the current socio-technical regime of finance suffers from a blatant regulatory deficit. As we have stressed already, there is a pressing need for regulators to step in and design financial regulations that tackle the systemic risks posed by climate change.

Finally, finance is increasingly technologically intensive. The wide-spread development of electronic stock trading and the adoption of digital information and communication technologies in the last decades underpinned significant spatial reconfigurations in the financial industry. For instance, Engelen and Grote argue that virtualization was central in the consolidation of leading financial centres (London and New York in particular) as well as the demise of second tier financial centres, such as Amsterdam and Frankfurt [55]. More recently, following the last financial crisis, we are also witnessing a remarkable growth in technologically intensive passive investments driven by new kinds of financial institutions and financial centres, where finance and technological-innovation increasingly work symbiotically [56]. These developments offer both opportunities and challenges for sustainable finance.

Ultimately, our framework sketches how sustainable finance, a potential new socio-technical regime of finance that addresses key societal challenges, emerges, co-evolves, and breaks through. This has implications beyond finance. Indeed, ESG outcomes are often preconditioned by financial arrangements. By creating and allocating credit, and translating savings into investments, financial 
intermediaries find themselves at the nexus of the three most important actors in sustainability transitions, namely governments, private corporations, and investors. Their in-depth knowledge of markets and privileged access to powerful economic institutions simultaneously makes them salient stakeholders and agents of change in sustainability transitions. As such, the transition to a sustainable finance regime has a fundamental role to play in enabling and accelerating sustainability transitions across other socio-technical systems (energy, transport, and manufacturing to name a few).

Finally, the framework postulates that bottom-up dynamics encompass innovations that offer alternative technical modalities to those proposed in the established regime. Initially, such innovations do not compete with the established regime, but grow separately in niches. As such, they pose no threat to the existing regime. As Sengers et al. put it: "Niches are the loci where radical (as opposed to incremental) innovations can develop without being subjected to the harsh selection pressures of the prevailing regime" [40] (p. 16). This typically describes grassroot forms of finance-led activism, such as the anti-apartheid movement as well as shareholder initiatives led by religious groups. The former is widely recognised by scholars as a central source of inspiration for later forms of finance-led activism (see, for instance, $[27,57,58]$ ). In later phases, as niche innovations find wider acceptance, they start competing with the established regime or can be co-opted by incumbents-the increasing ubiquity of investments labelled SRI [23], ESG indices, and rating agencies [59] are good examples of the latter dynamic. Sustainable finance is thought to emerge as an alternative socio-technical regime as disparate niche innovations breakthrough and are linked together into a cohesive proposition that challenges the existing regime of mainstream finance. Ultimately, a sustainable finance regime requires sustainable development goals to be fully integrated across its seven pillars (the industry of finance, market and user preferences, the science of finance, the cultures of finance, technology, regulation, and policy). In turn, this new socio-technical regime may come to exert an influence on the landscape. A sustainable regime of finance might, for instance, help promote top-down policies aimed at decoupling environmental degradation from economic growth [60].

As we have argued earlier, finance is undergoing significant yet still disparate and insufficient transformations. First, while the last decades have yielded plenty of innovations-SRI, ESG metrics, ethical banking, carbon markets, green bonds, and sustainable stock exchanges to name a few-their adoption by incumbent institutions is still at an early exploratory stage. As illustrated with the example of the Royal Bank of Canada, financial institutions are yet to design firm wide sustainable finance policies to be implemented indiscriminately across their business segments, from asset management to commercial banking. Second, there are important segments of the financial sector's value chain that crucially need engagement and innovation. Investment banks' underwriting services is one of these segments. Every year, investment banks help corporations and governments raise trillions of US dollars. In spite of underwriting's central importance in the creation of new finance, it has received little to no attention from sustainable finance scholars and practitioners alike. We address this gap here.

\section{Investment Banks' Treatment of Unethical Corporations in Primary Markets}

\subsection{Methods}

The following analysis merges datasets from Dealogic and the Norwegian Government Pension Fund Global (GPF-G) to assess the sustainability of investment banks' underwriting services. While the former provides investment banking data, we use the latter's list of excluded companies. We piggy-back on the GPF-G's established track-record in researching and flagging sub-standard corporate behaviour. As explained in the introduction, we define sustainable finance in line with the Brundtland Commission (1987) —that is, finance that protects the fundamental right of "all human beings" to "an environment adequate for their health and well-being" and safeguards inter-generational equity [44]. Furthermore, for the purpose of our analysis, we follow Sigurthorsson [12], who builds on the work of the philosopher, John Rawls, to distinguish between negative and positive duties: 
... in a business context, a negative duty requires merely that companies refrain from certain action, such as strategies and conduct that will certainly and foreseeably, or even just potentially, lead, or contribute, to some harm for society. Examples of such harm might be infringement of human rights, undue pollution of the environment or jeopardising economic and social stability in a given stakeholder community, to name a few [12] (p. 148)

By flagging investment banking deals involving companies excluded by the GPF-G, we de facto limit the scope of our analysis to only assess investment banks' compliance with negative duties, i.e., their compliance with the minimum standards of sustainability. We come back to this limitation in the conclusion. With over 20 years of global capital market investment experience, more than a decade-long practice of sustainable investment, and assets of over 1 trillion USD, the GPF-G is in many ways a pioneer and a leader in sustainable finance. The fund was set up by the Norwegian government in 1996 to smooth the impact of the booming oil and gas industry on its relatively small economy. As the fund's assets grew, a key challenge for the government-run fund was to prevent short-term political agendas interfering with the long-term interests of the Norwegian people. Therefore, the government decided that its assets would fund future pension liabilities. This long-term intergenerational objective was thought to protect the fund from short-term political interferences. It also had the effect of aligning the investment objectives of the fund with long-term sustainable investment practices.

The fund is owned by the Norwegian people and managed by Norway's central bank (Norges Bank) on behalf of the ministry of finance. Contrary to what its name suggests, the GPF-G is technically a sovereign wealth fund. Although it has the objective to fund future pension deficits, it does not manage pension labilities. As such, it has greater flexibility than a pension fund in the way it manages its assets. On the other hand, it is subject to public scrutiny and ought to be managed in a way that is consistent with Norwegians' expectations of good investment management. Consequently, Clark and Monk argued that the fund's objective is somewhat divided between fostering political legitimacy at home and producing optimal investment returns [61]. To foster its legitimacy, the fund has a clearly stated mission, which aims at balancing its financial objectives with its ESG objectives.

To meet its ESG objectives, the fund uses several methods. The first one is to actively exercise its ownership rights to engage with invested companies. To do so, the fund leverages its considerable financial power to change the behaviour of the companies it invests money in. The practice is argued to promote not only the fund's financial interests, but also collective welfare. The second method is to use divestment and exclusion to disengage with companies that are considered to fall below certain standards. In general, these companies either produce goods or behave in a way that is fundamentally inconsistent with the fund's ethical guidelines. These guidelines are formulated by an Ethics Council, who is also responsible for conducting research to motivate the exclusion of companies. The council was founded in order to deflect claims over conflicts of interest and political interferences as finance ministers used to run these tasks on their own. The Ethics Council follows a strict procedure and each exclusion is accompanied by a public statement. This naming-and-shaming strategy arguably functions as a means to increase the fund's legitimacy at home and further signals bad corporate citizenship to global financial markets. The Ethics Council first excluded 19 producers of nuclear weapons and 9 producers of cluster munitions in 2005. Since then, it has excluded a total of 153 companies. The list is publicly available from the Norwegian central bank's website. Table 1 provides a summary of the qualitative and quantitative characteristics of the list of excluded companies.

There are two main types of exclusions. The first one focuses on corporate misconduct in relation to environmental damage, gross corruption, and violations of human rights. The second relates to the type of goods produced by companies and includes tobacco, coal, nuclear weapons, and cluster munitions. The product exclusions are somewhat arbitrary. They reflect normative values of what is considered proper. Here, one might ask where the line should be drawn, a question which entails perhaps more complex ethical dimensions than the behaviour-based exclusions. For instance, the Norwegian fund has no explicit policies regarding companies that produce alcohol or military equipment. 
Table 1. Summary of the companies excluded from the GPF-G investment universe. Source: authors, based on Norges Bank Investment Management (NBIM) data.

\begin{tabular}{lclcc}
\hline $\begin{array}{l}\text { Type of } \\
\text { Exclusion }\end{array}$ & $\begin{array}{c}\text { No. of Companies } \\
\text { Excluded }\end{array}$ & Reason for Exclusion & $\begin{array}{c}\text { No. of Companies } \\
\text { Excluded }\end{array}$ & First Exclusion \\
\hline \multirow{4}{*}{ Conduct based } & \multirow{3}{*}{36} & Severe environmental damage & 23 & 06.06 .2006 \\
& & $\begin{array}{l}\text { Other serious violations of ethical norms } \\
\text { Serious violations of individuals' rights in }\end{array}$ & 6 & 03.09 .2009 \\
& & stiutations of war or conflict & 3 & 15.06 .2012 \\
& & Serious violations of human rights & 3 & 06.06 .2006 \\
& & Gross corruption & 1 & 07.01 .2016 \\
\hline \multirow{3}{*}{ Product based } & \multirow{2}{*}{117} & Production of coal or coal based energy & 69 & 14.03 .2016 \\
& & Production of tobacco & 20 & 19.01 .2010 \\
& & Production of nuclear weapons & 19 & 02.09 .2005 \\
& & Production of cluster munitions & 9 & 02.09 .2005 \\
\hline
\end{tabular}

While we recognize these limitations, we find this list fit for our purpose for the following reasons: Firstly, because of its size and its established track-record, the GPF-G is a highly regarded institution that shapes norms and practices among institutional investors. This list not only serves the fund's ethical missions, but further signals problematic corporate products and behaviour to global financial markets. Secondly, our results on investment banking have direct relevance to the GPF-G's own investment practices and could be meaningful in motivating the fund to expand its active ownership efforts to investment banks, an aspect of sustainable finance which remains under-appreciated and under-theorized.

Keeping these limitations in mind, we use the GPF-G's blacklist to filter through the Dealogic equity and debt capital markets dataset. We start our analysis in 2005 when the GPF-G made its first exclusion. Our investment banking dataset spans the years between 2005 and 2017 and includes 357,135 debt and 82,495 equity underwriting deals. An important aspect of the following analysis is timing. In general, corporate practices tend to adapt to landscape developments and niche innovations with significant time lags. Our objective is to evaluate how banks treat corporations that fail to meet the most basic standards of sustainable corporate practices across the ESG dimensions. We call such corporations "dirty". Furthermore, we coin the practice of underwriting the debt and equity of such corporations "dirty banking". For the behaviour exclusions, we flag investment banking deals that are made after the GPF-G's exclusion. While the mis-behaviours often precede the exclusion date by years, we assume that the formal exclusion constitutes a key moment in establishing credible proof of corporate malfeasance.

For the product-based exclusions, we take a different approach. Nuclear weapons and cluster munitions were excluded in 2005 and therefore all the investment banking deals involving such companies are flagged as dirty from 2005 onwards. On the other hand, tobacco and coal companies were only excluded in 2010 and 2016, respectively. We decide, however, to treat all the deals involving coal and tobacco companies as dirty from 2005 onwards. We believe the body of evidence regarding the negative health consequences of the former and the negative environmental consequences of the latter available to the public and the investment community back in 2005 to be compelling enough to label coal and tobacco companies as dirty from 2005.

In the United States, the first Surgeon General's report on the negative health consequences of smoking dates back to 1964. Three decades later, in the late 1990s, the United States Department of Justice took action to sue major tobacco companies. It took another 10 years for the GPF-G to blacklist tobacco companies from its investment universe. This slow process may reflect path dependency as institutions take time to change. Perhaps most importantly, they also reflect the opportunity cost that comes with blacklisting highly performing sectors and companies. Since the mid 1990s, British American Tobacco delivered a performance five times superior than that of the US stock market. While this may represent an investment dilemma, we think that the social implications of investing in tobacco companies were clear prior to 2010. 
Similarly, the environmental costs and health effects of coal-based energy production and consumption have been exposed and debated for at least two decades. As discussed earlier, we only now witness grassroots initiatives from financial institutions to step away from coal financing. Given the marked underperformance of the sector relative to global capital markets, the change in industry norms is perhaps less surprising. While we concede that this remains an important shift, we maintain that the evidence available at the time was compelling enough to label coal producers as dirty since 2005.

The approach we take with product-based exclusions has the effect of smoothing the sample of dirty companies through time. Figure 2 compares the cumulative number of blacklisted companies using the GPF-G exclusion dates and our alternative sampling method. Our approach gives us a sample of 117 dirty companies in 2005, growing steadily to 153 in 2017. On the other hand, the GPF-G's sample grows from 10 dirty companies in 2005 to 75 in 2015 to then jump to 142 in 2016 due to the addition of a long list of coal companies.

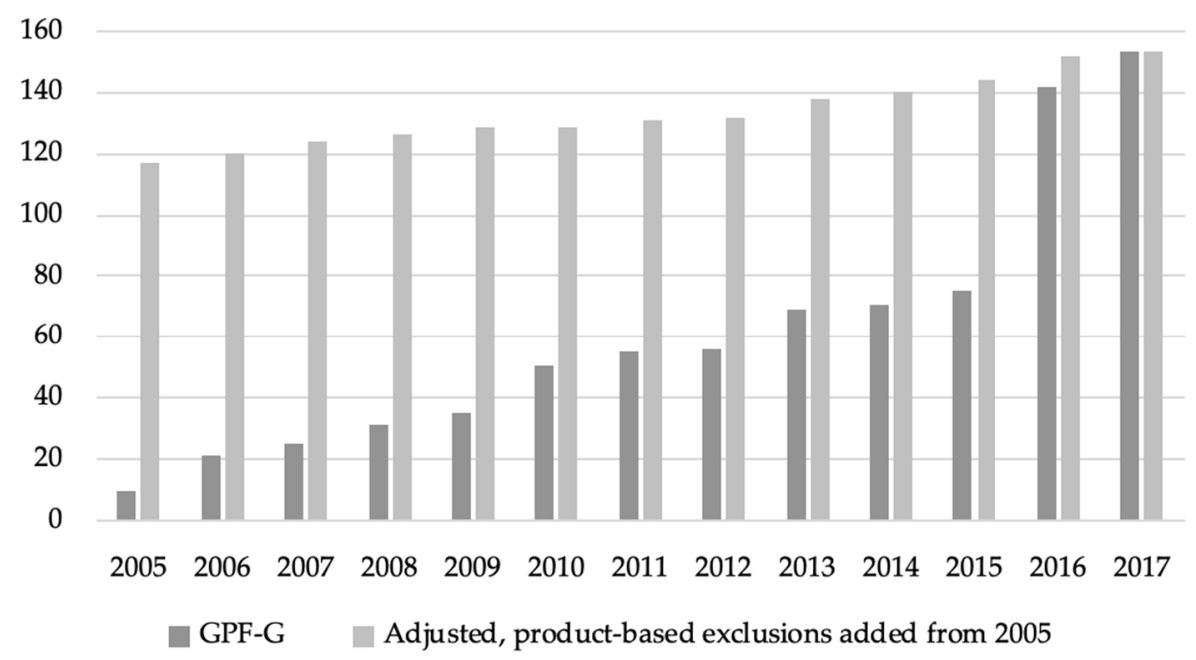

Figure 2. Number of dirty companies, cumulative, 2005 to 2017. Source: Authors' calculations, based on NBIM data.

Dealogic databases offer hundreds of variables on equity and debt underwriting deals. First, we focus on identifying the banks that offer investment banking services to dirty companies. In addition, we collected data on the monetary value of the debt and equity issued by dirty companies, and the net revenues banks earned from such deals. Net revenues are estimated by Dealogic. Estimates for individual deals have a $3-5 \%$ margin of error, which is acceptable for the purpose of our study. Our final dataset includes 439,594 investment banking deals starting 01.01.2005 and ending 31.12.2017. These deals pertain to both dirty and non-dirty clients. They include 357,135 debt issues for which we have 298,428 data points for deal size (face value of the issue). We have 923,536 data points for net revenues, each corresponding to the revenues generated for each participating bank. The dataset also includes 82,459 equity issues for which we have 69,070 data points for deal value. We have 206,327 data points for the net revenues generated for each of the participating banks.

We used a manual key-words search to retrieve dirty companies from the main dataset. Given the size of the dataset, the manual recovery was cumbersome, but necessary to insure the robustness of the analysis. In particular, it helped to flag a number of cases requiring further investigation. For instance, we flagged subsidiaries of excluded coal companies that strictly focus on non-coal energy production, ranging from gas to wind and solar. For instance, DTE Gas Co is a natural gas subsidiary of DTE Energy Co, which is excluded for coal. We did not label the financing of DTE Gas Co as dirty. This segregated corporate structure in the energy sector is very probably a response to investors' demand for strictly non-coal and clean energy investment opportunities. Finally, while most deals involve the parent companies themselves, a small number of the transactions were conducted via subsidiaries that 
function as special purpose financing entities. An example would be BAT International Finance p.l.c., which finances British American Tobacco p.l.c. The investment banking deals going through such subsidiaries were classified as dirty.

\subsection{Dirty Banking-Scope and Depth of the Market}

First, we present key metrics on the investment banking market between 2005 and 2017, focusing on the dollar amount of equity and debt issued, and investment banking net revenues. We examine the market as a whole and introduce key findings on the relative size as well as qualitative aspects of the market for dirty banking. Between 2005 and 2017, 80,476 individual companies spanning every corner of the globe used investment banking services to issue new debt and equity. In total, 91.3 trillion USD of new capital was raised-an average of 7 trillion every year. Debt financing accounted for about $90 \%$ of the money raised each year. We retrieved investment banking deals involving 124 of the 153 companies blacklisted by the GPF-G. In total, these 124 dirty companies raised 762 billion of new capital between 2005 and $2017-0.83 \%$ of the 91.3 trillion USD raised in total over the period. Figure 3 provides a year-by-year breakdown of these results.

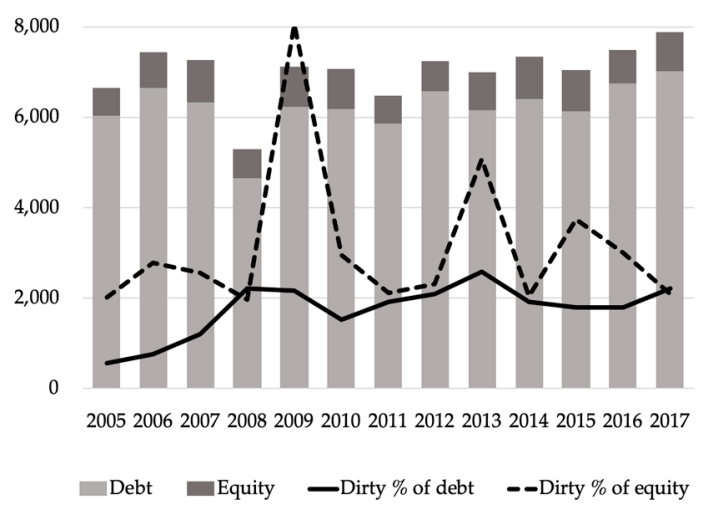

(a)

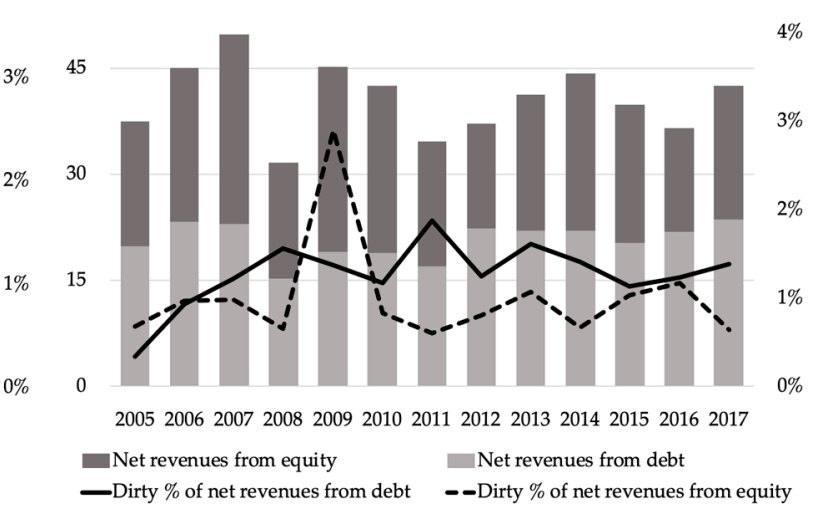

(b)

Figure 3. Equity and debt issued (a), and net revenues (b) from equity and debt underwriting, in billions of USD, 2005 to 2017. Source: Authors' calculations, based on Dealogic and NBIM data.

Between 2005 and 2017, debt and equity underwriting services generated 527.7 billion USD in net revenues-an average of 40.6 billion USD per year. For a given amount of new capital issued, equity underwriting generates far more revenues than debt underwriting. Indeed, net revenues were split more or less equally between debt and equity underwriting (yet debt makes up $90 \%$ of the issued capital). Over the period, investment banks accumulated 6.1 billion in net revenues from offering underwriting services to dirty clients- $1.2 \%$ of the total net revenues. $55 \%$ of these revenues came from debt and $45 \%$ from equity underwriting. Dirty debt issuance, and dirty debt underwriting revenues, have increased steadily over the period. Dirty equity issues and revenues on the other hand were quite volatile.

Dirty companies appear to raise a larger proportion of equity than other companies-on average, dirty equities make up $19 \%$ of the dirty capital raised each year. This finding is linked to the larger appetite for equity from companies in the extractive industries, which dominate our sample of dirty companies. Dirty companies account for about $1.4 \%$ of the capital raised via equity and $0.8 \%$ of the capital raised via debt issues (average per year). The 2009 peak in dirty equity issues and net revenues is attributed first and foremost to Rio Tinto (l.t.d. and p.l.c.) and Barrick Gold, which issued 16 billion USD and 4 billion USD worth of new equities, respectively, that year. Rio Tinto and Barrick Gold, two leading global mining companies, were, respectively, the largest and fourth-largest dirty banking clients over the period. We expand on the two companies in the next section dedicated to the top five dirty banking clients. 
Next, we propose to introduce a qualitative dimension using the exclusion categories identified by the GPF-G to analyse the total dirty capital issued and dirty banking net revenues between 2005 and 2017. The results are presented in Table 2.

Table 2. Dirty equity and debt issued and net revenues by exclusion type, billions of USD, 2005 to 2017.

\begin{tabular}{lcccccc}
\hline & $\begin{array}{c}\text { Share of Dirty } \\
\text { Capital } \\
\text { Issued }\end{array}$ & $\begin{array}{c}\text { Capital } \\
\text { Issued, } \\
\text { bn USD }\end{array}$ & $\begin{array}{c}\text { Debt \% of } \\
\text { Capital }\end{array}$ & $\begin{array}{c}\text { Equity \% of } \\
\text { Capital }\end{array}$ & $\begin{array}{c}\text { Share of } \\
\text { Dirty Net } \\
\text { Revenues }\end{array}$ & $\begin{array}{c}\text { Net } \\
\text { Revenues, } \\
\text { bn USD }\end{array}$ \\
\hline Production of coal or & $37 \%$ & 278.90 & $72 \%$ & $28 \%$ & $45 \%$ & 2.76 \\
coal-based energy & $19 \%$ & 144.69 & $91 \%$ & $9 \%$ & $13 \%$ & 0.78 \\
Production of tobacco & $17 \%$ & 132.27 & $88 \%$ & $12 \%$ & $12 \%$ & 0.72 \\
Production of nuclear weapons & $14 \%$ & 107.93 & $65 \%$ & $35 \%$ & $22 \%$ & 1.32 \\
Severe environmental damage & $7 \%$ & 53.78 & $100 \%$ & $0 \%$ & $4 \%$ & 0.27 \\
Serious violations of human rights & $6 \%$ & 42.04 & $95 \%$ & $5 \%$ & $4 \%$ & 0.23 \\
Production of cluster munitions & $0 \%$ & 2.86 & $75 \%$ & $25 \%$ & $0 \%$ & 0.02 \\
Other serious violations & $100 \%$ & 762.47 & na & na & $100 \%$ & 6.09 \\
\hline TOTAL & & &
\end{tabular}

Source: Authors' calculations, based on Dealogic and NBIM data.

Coal companies were not only the largest issuers of dirty capital; their demand for new finance has consistently increased between 2005 and 2017. This comes at a slight surprise given the intensifying criticism towards coal's sustainability and the general underperformance of the sector. As discussed earlier, there is a notable lending squeeze imposed on coal companies. Possibly, the pressure put on bank loans may be already compensated by capital market equity and debt issuance-if true, this hypothesis reinforces the importance of extending Scholtens' argument to include underwriting.

Our results on tobacco companies show that a decade of pressures-taxation and smoking bans in particular-have not deterred tobacco companies from increasing their demand for new finance over the period. Unfortunately, the efforts to reduce tobacco consumption made in countries, such as the United Kingdom, Brazil, and Australia, have been more than offset by the increasing demand from emerging economies-in 2016, 2.4 trillion cigarettes (40\% of the global consumption) were smoked in China alone, a 26\% increase since 2005 [62]. While tobacco companies are first in line in public health debates, we think the responsibility of the banks that help them to issue new finance should not be understated.

Interestingly, all the companies flagged for severe environmental damage belong to the extractive industry and almost all of them are mining companies- $98 \%$ of the dirty banking revenues linked to environmental damage came from mining companies. We analyse the main issuers in the next section in more detail. The exclusion category, "serious violations of human rights", includes only Wal-Mart-more details are also provided in the next section. The sixth largest group of dirty capital issuers are producers of cluster munitions. It involves eight companies, six of which are pure aerospace and defence companies, and another two industrial conglomerates with dedicated operations to manufacture defence products.

Finally, we note that the exclusion category, "serious violation of fundamental ethical norms", includes four corporations all involved with contentious natural resource extraction and exploration in the disputed territory of Western-Sahara. A key issue is that resource extraction in the region does not benefit the local population. Potash Corporation of Saskatchewan Inc. and FMC Corporation have been excluded by the GPF-G for purchasing phosphate from the Moroccan company, Office Cherifien des Phosphates (OCP). The OCP is an organisation that extracts phosphate in Western-Sahara. Potash Corporation of Saskatchewan Inc and FMC Corporation are both knowingly purchasing phosphate from the region with no intention to change their sourcing. The other two companies are Kosmos Energy and San Leon Energy, which were excluded by the GPF-G for their offshore hydrocarbon explorations on behalf of the Moroccan authorities in Western Sahara [63]. 


\subsection{Dirty Banking—Dirty Clients}

Now that we have a broad view of the market for dirty investment banking, we propose to review the qualitative features of some of the largest clients for dirty investment banking underwriting services. To be sure, our primary argument pertains to investment banks' responsibility in facilitating access to capital for problematic corporate activities and practices. Yet, we would not want to downplay the responsibility of dirty corporations. To address this, the following section proposes to connect the world of finance with the rest of the economy. For practical reasons, we focus on the top five dirty banking clients (by net revenues). These five dirty clients (out of 124) accounted for $28 \%$ of the dirty net revenues accumulated by investment banks between 2005 and 2017. Key results are summarized in Table 3 and discussed hereafter.

To complement our discussion, we also manually collected and analysed the Securities Exchange Commission's (SEC) prospectuses filed by these five companies between their exclusion date and 2017. These prospectuses include the SEC Forms 424(B)(2), 424(B)3, and 424(B)5, which are legal documents supposed to inform prospective investors of the risks associated with purchasing the newly issued securities. In reviewing these documents, we focused on how companies understand and communicate the ESG dimensions of newly issued debt and equity securities with prospective investors. We paid particular attention to how Rio Tinto, Freeport-McMoRan, NRG Energy, and Barrick Gold communicate environmental risks and how Wal-Mart communicates social issues, particularly human rights and labour.

Rio Tinto is a global mining and metals company and was the largest contributor to dirty net revenues with 494 million USD. These revenues are aggregated at a group level and relate to Rio Tinto plc, which is headquartered in London, United Kingdom, and Rio Tinto ltd, headquartered in Melbourne, Australia. Both were formally excluded by the GPF-G in 2008 for severe environmental damage. The exclusion was centred around improper disposal of mining tailings at the gold and copper Grasberg mine in Indonesia. The mine is primarily owned and operated by Freeport-McMoRan Inc, which was the subject of a separate exclusion. Freeport-McMoRan Inc was the second largest contributor to dirty net revenues with 345 million USD. Freeport is a mining company headquartered in Phoenix, Arizona. It produces copper, gold, petroleum, and molybdenum (a chemical element used in metallurgy for alloy manufacturing). The company was excluded by the GPF-G in relation to severe environmental damage in 2006.

The fund's Ethics Council recommended that Freeport be excluded in relation to the dumping of approximately 230,000 tonnes of mining tailings per day into a river system at the Grasberg mine [64]. The tailings, which contain sediments and heavy metals, including copper, cadmium, and mercury, were found to have caused severe damage to the river system and the rainforest and generated serious negative outcomes for the people living in the area. Rio Tinto's later exclusion is based upon a second review (2008), which led the Ethics Council to establish its material involvement in Freeport's operations at the Grasberg mine (ibid).

According to the Ethics Council, Indonesia and Papua New Guinea are the only remaining countries in the world to still allow riverine mining tailings disposal; a leniency in local environmental regulation that Freeport and Rio Tinto are thought to abuse in order to reduce the costs of their waste management programs. As emphasised in the exclusion decision related to Freeport, the company has expressed no intention to alter its practices despite the well-established ecological and health hazards associated with its current practices. At the end of 2005, the Ethics Council sent a letter to Freeport to report on their findings and offer the company a chance to respond. Freeport replied within two months, refuting the allegations yet failing to provide evidence to support their position. Since the Grasberg mine is expected to remain profitable until 2041, the Ethics Council expects severe and lasting environmental damages to result from the two mining companies' misconduct (ibid). 
Table 3. Top five dirty clients, 2005 to 2017. * Conduct-based exclusions relate to deals ex-post exclusion, product-based exclusions cover the whole time period.

\begin{tabular}{|c|c|c|c|c|c|c|c|}
\hline & GPF-G Exclusion Date & Reason for Exclusion & $\begin{array}{l}\text { Value of Equity } \\
\text { Issued *, bn USD }\end{array}$ & $\begin{array}{l}\text { Value of Debt } \\
\text { Issued *, bn USD }\end{array}$ & $\begin{array}{l}\text { Underwriting Net } \\
\text { Revenues on } \\
\text { Equity Deals*, } \\
\text { mn USD }\end{array}$ & $\begin{array}{l}\text { Underwriting } \\
\text { Net Revenues on } \\
\text { Debt Deals*, } \\
\text { mn USD }\end{array}$ & $\begin{array}{c}\text { Total } \\
\text { Underwriting Net } \\
\text { Revenues* } \\
\text { mn USD }\end{array}$ \\
\hline Rio Tinto, Plc \& Ltd. & 09.09 .2008 & Severe envrionmental damage & 16.7 & 21.6 & 409.6 & 84.9 & 494.4 \\
\hline Freeport-McMoRan Inc & 06.06 .2006 & Severe envrionmental damage & na & 18.5 & 148.6 & 196.5 & 345.0 \\
\hline NRG Energy Inc & 21.12.2016 & Coal & 3.0 & na & 52.4 & 245.6 & 298.1 \\
\hline Barrick Gold Corp & 30.01 .2009 & Severe envrionmental damage & 8.2 & 9.8 & 258.5 & 22.1 & 280.6 \\
\hline Wal-Mart Stores Inc & 06.06 .2006 & Serious violations of human rights & 0.0 & na & 0.0 & 266.6 & 266.6 \\
\hline TOP 5 TOTAL & & & 27.8 & 49.9 & 869.0 & 815.7 & 1684.7 \\
\hline
\end{tabular}

Source: Authors' calculations, based on Dealogic and NBIM data 
Following the exclusion in 2006, the GPF-G divested its 15 million USD investment in Freeport and, in 2008, divested its 625 million USD stake in Rio Tinto. Rio Tinto's investment banking deals were conducted not directly by Rio Tinto, but via subsidiaries that function as special purpose financing entities. It is interesting to note that Macquarie Group, the third bank to profit the most from servicing Rio Tinto back in 2009, was the bank selected to take over the Green Investment Bank from the UK government in 2017. Notwithstanding the significant time-lag, it again shows that banks seem to operate ethical silos that can function in almost fundamentally contradictory directions, i.e., promoting access to capital for a prime contributor to environmental degradation and the promotion of green infrastructure.

Of the five companies reviewed here, Rio Tinto features one of the most explicit treatments of ESG related risks in its SEC prospectuses. Most of the prospectuses include the following statement: "Rio Tinto operates in an industry that is subject to numerous health, safety and environmental laws, regulations and standards as well as community and stakeholder expectations" [65] (p. 10). Going into particulars, the prospectuses make explicit mentions of regulatory risks, reputation risks (community relations in particular), risks associated with unforeseen land rehabilitation costs, and climate change risks. The content of the prospectuses issued between 2008 and 2015 (we reviewed eight in total) is largely standardised and changes in small, but interesting ways over the years. Overall, when it comes to communicating on environmental (as well as social) risks, the company uses a language that invariably speaks of its own vulnerability rather than its responsibility.

Consider the following fragment: "Mining operations are vulnerable to natural disasters, including earthquakes, drought, floods, fire, tropical storms and the physical effects of climate change" (ibid, p9). Interestingly, in the prospectuses issued from 2011 onwards, the formulation "the physical effects of climate change" was changed to the more evasive "the possible effects of climate change" [66] (p. 10). What is most interesting in this statement is how it underscores a financialization of corporate responsibility. Indeed, the environment is understood not as a common good, but as a variable affecting investors' revenue streams. Within this framework, Rio Tinto faces micro-opportunities to profit from sub-standard environmental regulation and simultaneously faces macro-threats associated with climate change. What the company fails to identify and reconcile is its own contribution to the risks it is exposed to. We found no specific mention of risks pertaining to Rio Tinto's controversial activities at the Grasberg mine in Indonesia.

In its prospectuses, Freeport-McMoRan mentions similar environmental risks to Rio Tinto and also acknowledges potential climate change related risks. However, it uses a more conservative language: "The potential physical impacts of climate change on our operations are highly uncertain, and would be particular to the geographic circumstances" [67] (p. 23). Interestingly, Freeport's prospectus unpacks quite explicitly the risks specific to the Grasberg mine. Besides risks unrelated to climate change (difficult terrain, Indonesian political, social, and economic uncertainties), we find a mention of the company's tailing disposal practices. Here, the emphasis is placed on legitimatizing the practice. Several times, the company asserts that the use of the local river system has been approved by the government of Indonesia and that the practice has been vetted through several reviews conducted by a panel of international experts and the Indonesian Ministry of Environment (ibid).

NRG Energy was the third largest client for dirty banking services. It generated 298 million USD in net revenues between 2005 and 2017. NRG Energy is an American energy company with a dual headquarter in West Windsor Township, New Jersey and Houston, Texas. NRG Energy was excluded at the end of 2016 as part of the GPF-G's second tranche of exclusions concerning coal-based companies. Since 2016, the GPF-G has started due-diligence work aimed at excluding companies that base $30 \%$ or more of their activities on coal and/or generate $30 \%$ or more of their revenues from coal. As a result of the criterion used, both power and mining companies can be subject to exclusion. For reasons explained earlier, we flagged and included investment banking deals retrospectively for product-based exclusions. 
Reviewing NRG's prospectuses, we found a section on business strategy that features an explicit commitment to environmental sustainability. Notably, the company expresses its intention to: (i) "increase ... fuel diversity"; (ii) develop facilities with "near zero greenhouse gas ... or (that) can be equipped to capture and sequester greenhouse gas emissions"; and (iii) include "low or no (greenhouse gas) emitting energy generating sources, such as nuclear, wind, solar thermal, photovoltaic, 'clean' coal, and gasification, and the retrofit of post-combustion carbon capture technologies" [68] (p. 2). In its 2009 prospectus, the company lists very few ESG specific risks. Indeed, we only find passing references to environmental incidents and environmental laws, but the document provides little to no specifics.

In 2014, however, NRG's prospectuses feature far more detailed treatment of these topics. In particular, a 424(B)(3) filed on March 27 features entire sub-sections pertaining to regulatory risks on the topics of greenhouse gas regulation, cross-state air pollution rules, hazardous air pollutant regulations, water quality, and coal combustion wastes [69]. This far more hands-on approach to environmental regulation reflects the Obama administration's efforts to combat climate change. Indeed, since the 2009 presidential election, no less than 3900 new rules were introduced by the Environmental Protection Agency [70]. These regulatory changes are then reflected in the way the company perceives and communicates regulatory risks.

It is worth noting that since 2016, the Trump administration has been working hard to dismantle Obama's efforts. Among other measures, it is seeking to devolve coal-power regulation back to individual states [71]. While the news is nothing short of an environmental setback, it is likely to be received positively by NRG Energy and its investors (the stock is up 238\% since Trump's election in November 2016). This is typically a case of landscape developments that affect the way energy companies perceive and communicate on environmental issues. As a result, NRG Energy is likely to relax its environmental management efforts and downplay environmental regulation risks in its communications to investors. Besides the direct effect of deregulation, and provided that these prospectuses have influence on investors' expectations, these reversals might have the added indirect effect of reducing investors' environmental consciousness.

Barrick Gold was the fourth largest client for dirty investment banking services. It generated 281 million USD in underwriting net revenues between 2005 and 2017. Barrick Gold is headquartered in Toronto, Canada, and is the largest gold mining company in the world. It was excluded in January 2009 after an in-depth investigation of the company's environmental wrongdoings in the Porgera Mine in Papua New Guinea. The decision mentions that the geographical focus of the investigation relates to the limited resources the ethics committee has at its disposal and notes that Barrick faces allegations of environmental misconduct in several other locations (the company had 27 mines in operation at the time). Here again, the mining company is accused of dumping toxic waste in a nearby river, thereby causing serious environmental pollution and endangering human life and health [72]. Following the exclusion, Barrick Gold issued 8.16 billion USD worth of new equities. Half of it was issued in 2009, which explains the peak in dirty equities issuance and revenues that year (see Figure 3).

Barrick's prospectus includes a significant number of ESG related statements and information. A general risks section mentions environmental hazards and environmental costs relating to the compliance with, and monitoring of, environmental regulations as well as environmental remediation costs. The prospectus also features a section dedicated to stranded assets ("Assets retirement obligations"), which "arise from the acquisition, development, construction and normal operation of mining property, plant and equipment, due to government controls and regulations that protect the environment on the closure and reclamation of mining properties" [73] (p. 59). Finally, the prospectus also features a rather long list detailing ongoing litigations and claims. A number are directly related to improper disposal of mining tailings leading to environmental degradation, "injuries to health", and "economic damages to local fisheries" in the Philippines (ibid).

Wal-Mart Stores was the fifth largest client for dirty investment banking services. It contributed 267 million USD in dirty banking net revenues between 2005 and 2017. Wal-Mart, headquartered in 
Bentonville, Arkansas, is a global retailer that operates hypermarkets, department stores, and grocery stores. Wal-Mart was excluded by the GPF-G back in 2006 in one of the highest profile exclusions made by the Norwegian fund. The exclusion relates to the company's violations of human rights and labour rights. The decision states: "What makes this case special is the sum total of ethical norm violations, both in the company's own business operations and in the supplier chain" [64].

Among the most serious contraventions, the decision mentions "serious or systematic human rights violations, such as murder, torture, deprivation of liberty, forced labour, the worst forms of child labour and other forms of child exploitation" (ibid). The issues are asserted to be global and wide-spread enough to consider active engagement through ownership rights ineffective and warrant an exclusion. Wall-Mart's US labour-rights violations have been the object of a thorough investigation, which resulted in an unforgiving 210-page-long report published by Human Rights Watch [74]. As a result, the GPF-G divested 320 million USD from Wall-Mart. We searched for key words, including reputation, labour, proceedings, social, human, and community, in Wal Mart's prospectuses. We found no evidence of any engagement on these issues, but a generic mention of the risks associated with legal proceedings.

\section{Discussion and Conclusions}

One should note that the extent of the problem we uncovered here largely reflects the methods we employed. As explained in the methods section, our analysis focuses on corporations identified by the GPF-G for failing to meet the most basic standards of sustainable corporate practices across the ESG dimensions. As such, our paper sheds light on mal-practice (dirty banking) rather than best practice (sustainable investment banking). Using an alternative definition of dirty corporations, one that, for instance, includes all fossil fuel companies, would naturally inflate the scope of the problem. Ultimately, we hope that future research can address this limitation and propose a positive working definition of sustainable investment banking.

Between 2005 and 2017, we counted 5298 individual banks participating in the underwriting market. Of these banks, 393 underwrote the debt and equity of dirty clients. While this is less than $10 \%$ of the participating institutions, it should be emphasised that most, if not all, household names in investment banking took part in dirty deals. Overall, our results show that the largest investment banks by net revenues have the largest market shares of dirty net revenues. This finding suggests that investment banks treat dirty clients like any other and that they have little to no consideration for the ESG performance of their clients.

The market concentration amongst leading institutions is very significant in investment banking. This tendency is even stronger for dirty deals. The top five banks accounted for close to $40 \%$ of the total net revenues generated from dirty deals (compared with 31\% for all deals). On average, the 393 banks that serviced dirty clients derived $3.7 \%$ of their net revenues from dirty clients. This value is inflated by the tail end of our sample of dirty banks, where we found a significant number of smaller banks that generate an abnormal proportion of their revenues from servicing dirty clients. On average, the top 20 banks underwriting dirty companies generated $1.7 \%$ of their net revenues from dirty deals.

Since firm-level revenue shares from dirty clients are relatively small, we think there is a real opportunity for large institutional investors to actively engage banks servicing dirty companies and push them to improve their ESG standards in underwriting. The GPF-G, which has a long history of active ownership [51], could be a strategically important leader in this respect. Indeed, when reviewing the GPF-G's investment portfolio at the end of 2017, we retrieved 157 of the 393 banks that underwrite dirty companies. Specifically, the GPF-G's own investments in such banks amounted to 30.2 billion USD-18\% of the fund's investments in financials and $4 \%$ of the fund's total equity investments.

While we appreciate the difficulty for an asset owner of that size (the GPF-G weighs over 1 trillion USD) to consistently invest its assets in a way that balances financial objectives with social and environmental ones, we think that the fund's exposure to banks that underwrite dirty companies is problematic enough to warrant critical reflection and action. Indeed, this result means that, although 
indirectly and through a complex financial value chain, the GPF-G is still exposed to and benefits from the companies it blacklisted in the first place. To be sure, in an indirect way, the fund's financial assets provide funding to banks that are instrumental in helping environmentally and socially contentious firms to access funding of their own. Not only this creates a deontological paradox, it is likely to be consequential for the fund's investment returns. Indeed, as a large asset owner with long-term investment objectives, the GPF-G cannot shield its investments from negative social and environemental externalies [75]. As such, it has vested interests in pushing banks to stop facilitating access to finance for companies that cause social and environmental harm.

The GPF-G's investments in banks that underwrite dirty companies are sizeable enough to give the fund considerable weight in informal engagement tactics as well as shareholder initiatives. Indeed, its average investment in such banks is worth 304 million USD and several amount to more than 1 billion USD. These investments come with sizeable voting rights. While operationally it may be difficult for the GPF-G to engage each of the 157 problematic banks they have in their portfolio, the fund could start by engaging the top five (ranked by voting rights to maximise leverage). This could first be done by using informal engagement tactics, bringing up the issue during investor meetings. If unsuccessful, the initiatives could be extended to formal shareholder resolutions.

The GPF-G is a very powerful and highly regarded actor in sustainable finance. The fund's stance on ESG issues is known to foster international conversations and controversies-most recently, it has been the subject of heated debates and criticism for its hesitant stance on whether to divest from oil and gas (compare [76] with [77]). The fund's high visibility and huge financial power could be instrumental in setting best practices and gathering momentum within the investment community to require explicit firm-wide ESG policies from banks.

Ultimately, a successful active engagement campaign could increase the cost of capital of dirty companies. Indeed, if turned down by the largest investment banks, dirty companies would be forced to turn to smaller investment banking boutiques. Since smaller investment banks are less well connected with investors and other banks [2,3], their underwriting services are likely to be charged at a premium while the issued securities are more likely to be mispriced and sold at a discount.

As we have suggested, commercial banks' decisions to stop lending to contentious activities might already be pushing low ESG performers (coal companies in particular) to access new finance through capital markets. Testing these relationships empirically could offer very fruitful research endeavours and would help further Scholtens' call to tackle the problem of sustainable finance at the source [5]. In this respect, we think there is still much work to be done on the roles, responsibilities, and agency of financial intermediaries in the sustainability transition in finance. Indeed, a lot of attention has been given to getting asset owners to use ESG metrics to assess non-financial firms to make sustainable investment decisions. This is without a doubt an important piece of the puzzle. However, a sustainability transition in finance will not happen without getting intermediaries on board.

Law firms, consultants, and accounting firms-all instrumental in insuring new finance is raised in a timely, cost effective, and compliant way-have privileged access and in-depth knowledge of the companies they serve and as such are very well positioned to integrate ESG dimensions in their service provision. This could as much help them to assess prospective clients as help their clients to improve their environmental and social footprint. Here again, there are important questions to be asked on how this support structure values and integrates ESG metrics in their service provision. If only for reputation management, some firms might want to start developing and adopting best-practices and policies to assess risks associated with servicing contentious industries and clients. The recent commitment to ESG integration by major credit rating agencies, such as Moody's or Standard \& Poor's Global Ratings, should be welcomed as a step in the right direction. The following quote attributed to S\&P Global Ratings epitomizes a mindset one would hope to see spread across the financial sector: "Since all rated entities operate in the natural and social worlds, we regard these risks as ubiquitous across the ratings spectrum" [78] (p. 17). 
Underpinning our findings and broader reflections is a pressing need to develop a system-wide approach to sustainable finance amongst practitioners and scholars alike. As we have argued and demonstrated, although financial institutions are engaging with sustainable development goals in a number of innovative ways, the financial apparatus as a whole is failing its sustainability transition. The lack of cohesion is a core problem. Notwithstanding the challenge it represents, we think there is real potential to study and promote sustainable finance innovations, such as green bonds, sustainable bank lending, ethical banking, SRI, as well as sustainable investment banking, in conjunction rather than in isolation. This approach is what underpins our framework. Moving forward, we hope this first conceptualisation of finance as a socio-technical system can be deployed by scholars interested in answering our call to study as well as further theorize the sustainability transition in finance with a system approach.

Author Contributions: Conceptualization, M.A.U. and D.W.; methodology, M.A.U. and D.W.; formal analysis, M.A.U.; investigation, M.A.U. and D.W.; data curation, M.A.U.; writing-original draft preparation, M.A.U.; writing-review and editing, M.A.U. and D.W.; visualization, M.A.U. and D.W.; supervision, D.W.; project administration, M.A.U. and D.W.; funding acquisition, D.W.

Funding: This research was supported by the European Research Council (ERC) under the European Union's Horizon 2020 research and innovation programme (grant agreement number 681337). The ERC did not play any role in the formulation of the article's content and argument.

Acknowledgments: The authors thank Gordon Clark, Wilhelm Mohn, Alexis Wegerich, Caroline Eriksen, Sabine Dörry, Nina Haerter, Stefanos Ioannou and Rebecca Sandell for providing comments on previous drafts of this article. This paper was also presented under the same title at the 2018 Global Conference on Economic Geography in Cologne, and the 2018 FinGeo Spring School in Brussels. We would like to thank the participants of these conferences for their helpful comments. None of the above should be held responsible for the opinions expressed herein.

Conflicts of Interest: The authors declare no conflict of interest. The funders had no role in the design of the study; in the collection, analyses, or interpretation of data; in the writing of the manuscript, or in the decision to publish the results.

\section{References}

1. Arjaliès, D.-L.; Grant, P.; Hardie, I.; MacKenzie, D.; Svetlova, E. Chains of Finance: How Investment Management Is Shaped; Oxford University Press: Oxford, UK, 2017.

2. Jenkinson, T.; Jones, H. Bids and allocations in European IPO book building. J. Financ. 2004, 59, 2309-2338. [CrossRef]

3. Pollock, T.G.; Porac, J.F.; Wade, J.B. Constructing deal networks: Brokers as network "architects" in the U.S. IPO market and other examples. Acad. Manag. Rev. 2004, 29, 50-72. [CrossRef]

4. Jenkinson, T.; Jones, H. IPO pricing and allocation: A survey of the views of institutional investors. Rev. Financ. Stud. 2009, 22, 1477-1504. [CrossRef]

5. Scholtens, B. Finance as a Driver of Corporate Social Responsibility. J. Bus. Ethics 2006, 68, 19-33. [CrossRef]

6. Eccles, R.G.; Serafeim, G. The Performance Frontier: Innovating for a Sustainable Strategy. Harv. Bus. Rev. 2013, 91, 50-60.

7. Chih, H.; Chih, H.; Chen, T. On the determinants of corporate social responsibility: International evidence on the financial Industry. J. Bus. Ethics 2010, 93, 115-135. [CrossRef]

8. Pérez, A.; Rodríguez Del Bosque, I. The Role of CSR in the Corporate Identity of Banking Service Providers. J. Bus. Ethics 2012, 108, 145-166. [CrossRef]

9. $\mathrm{Wu}, \mathrm{W}$.; Shen, C.-H. Corporate social responsibility in the banking industry: Motives and financial performance. J. Bank. Financ. 2013, 37, 3529-3547. [CrossRef]

10. Cornett, M.M.; Erhemjamts, O.; Tehranian, H. Greed or good deeds: An examination of the relation between corporate social responsibility and the financial performance of U.S. commercial banks around the financial crisis. J. Bank. Financ. 2016, 70, 137-159. [CrossRef]

11. Marshall, N.; Dawley, S.; Pike, A.; Pollard, J. Geographies of corporate philanthropy: The Northern Rock Foundation. Environ. Plan. A 2018, 50, 266-287. [CrossRef]

12. Sigurthorsson, D. The Icelandic Banking Crisis: A Reason to Rethink CSR? J. Bus. Ethics 2012, 111, 147-156. [CrossRef] 
13. Milano, R. Social Banks and the Future of Sustainable Finance; Routledge: New York, NY, USA, 2011; pp. $15-47$.

14. Carroll, A.B. Corporate Social Responsibility Evolution of a Definitional Construct. Bus. Soc. 1999, 38, 268-295. [CrossRef]

15. Clark, G.L.; Salo, J.; Hebb, T. Social and environmental shareholder activism in the public spotlight: US corporate annual meetings, campaign strategies, and environmental performance, 2001-2004. Environ. Plan. A 2009, 40, 1370-1391. [CrossRef]

16. Westermann-Behaylo, M. Institutionalizing Peace through Commerce: Engagement or Divestment in South African and Sudan. J. Bus. Ethics 2009, 89, 417-434. [CrossRef]

17. Friedman, M. The Social Responsibility of Business is to Increase its Profits. The New York Times Magazine, 13 September 1970.

18. Davis, K. The Case for and against Business Assumption of Social Responsibilities. Source Acad. Manag. J. 1973, 16, 312-322. [CrossRef]

19. Soana, M.-G. The Relationship Between Corporate Social Performance and Corporate Financial Performance in the Banking Sector. J. Bus. Ethics 2011, 104, 133-148. [CrossRef]

20. Van Beurden, P.; Gössling, T. The Worth of Values-A Literature Review on the Relation Between Corporate Social and Financial Performance. J. Bus. Ethics 2008, 407-424. [CrossRef]

21. Clark, G.L.; Feiner, A.; Viehs, M. From the Stockholder to the Stakeholder: How Sustainablity Can Drive Financial Performance 2015. Available online: http:/ / ssrn.com/abstract=2508281 (accessed on 20 March 2019).

22. GSIA. Global Sustainable Investment Review 2016. Available online: http://www.gsi-alliance.org/wpcontent/uploads/2017/03/GSIR_Review2016.F.pdf (accessed on 20 March 2019).

23. Richardson, B.J. Keeping Ethical Investment Ethical: Regulatory Issues for Investing for Sustainability. J. Bus. Ethics 2009, 87, 555-572. [CrossRef]

24. Benedetti Valentini, F; Ward, R. BNP to Halt Shale Oil Financing, Expand Funds for Renewables, Bloomberg 2017. Available online: https://www.bloomberg.com/news/articles/2017-10-11/bnp-paribas-to-halt-shaleoil-financing-in-climate-change-pledge (accessed on 23 December 2018).

25. The Guardian. Deutsche Bank Pulls Out of Coal Projects to Meet Paris Climate Pledge. The Guardian. 2017. Available online: https: / www.theguardian.com/business/2017/feb/01/deutsche-bank-pulls-out-of-coalprojects-to-meet-paris-climate-pledge (accessed on 23 December 2018).

26. Ran.org. Banking on Climate Change: Fossil Fuel Finance Report Cart 2018. Available online: http:/ / www.ran.org/wp-content/uploads/rainforestactionnetwork/pages/19540/attachments/ original/1525099181/Banking_on_Climate_Change_2018_vWEB.pdf?1525099181 (accessed on 23 December 2018).

27. Muñoz-Torres, M.J.; Fernández-Izquierdo, M.Á.; Rivera-Lirio, J.M.; Ferrero-Ferrero, I.; Escrig-Olmedo, E.; Gisbert-Navarro, J.V.; Marullo, M.C. An assessment tool to integrate sustainability principles into the global supply chain. Sustainability 2018, 10, 535. [CrossRef]

28. Tischer, D. Swimming against the tide: Ethical banks as countermovement. J. Sustain. Financ. Invest. 2013, 3, 314-332. [CrossRef]

29. Kaufer, K. Social responsibility as a core business model in banking: A case study in the financial sector. J. Sustain. Financ. Invest. 2014, 4, 76-89. [CrossRef]

30. Geels, F.W. From sectoral systems of innovation to socio-technical systems Insights about dynamics and change from sociology and institutional theory. Res. Policy 2004, 33, 897-920. [CrossRef]

31. Geels, F.W. The dynamics of transitions in socio-technical systems: A multi-level analysis of the transition pathway from horse-drawn carriages to automobiles (1860-1930). Technol. Anal. Strateg. Manag. 2005, 174, 445-476. [CrossRef]

32. Smith, A.; Stirling, A.; Berkhout, F. The governance of sustainable socio- technical transitions. Res. Policy 2005, 34, 1491-1510. [CrossRef]

33. Geels, F.W. Ontologies, socio-technical transitions (to sustainability), and the multi-level perspective. Res. Policy 2010, 39, 495-510. [CrossRef]

34. Shove, E.; Walker, G. CAUTION! Transitions ahead: Politics, practice and sustainable transition management. Environ. Plan. A. 2007, 39, 763-770. [CrossRef]

35. Wiskerke, J.S.C.; Van der Ploeg, J.D. Seeds of Transition: Essays on Novelty Production, Niches and Regimes in Agriculture; Royal Van Gorcum: Assen, The Netherlands, 2004. 
36. Smith, A. Strategic Management Translating Sustainabilities between Green Niches and Socio-Technical Regimes. Technol. Anal. Strateg. Manag. 2007, 19, 427-450. [CrossRef]

37. Van den Bergh, J.C.J.M. Managing the Transition to Renewable Energy: Theory and Practice from Local, Regional and Macro Perspectives; Bruinsma, F.R., Ed.; Edward Elg: Cheltenham, UK, 2008.

38. Geels, F.W. The impact of the financial-economic crisis on sustainability transitions: Financial investment, governance and public discourse. Environ. Innov. Soc. Transit. 2013, 6, 67-95. [CrossRef]

39. Pathania, R.; Bose, A. An analysis of the role of finance in energy transitions. J. Sustain. Financ. Invest. 2014, 4, 266-271. [CrossRef]

40. Sengers, F.; Wieczorek, A.J.; Raven, R. Experimenting for sustainability transitions: A systematic literature review. Technol. Forecast. Soc. Chang. 2016. [CrossRef]

41. Merton, R.C. A Functional Perspective of Financial Intermediation. Financ. Manag. 1995, 24, 23-41. [CrossRef]

42. Scholtens, B.; van Wensveen, D. The Theory of Financial Intermediation: An Essay on What It Does (Not) Explain 2003. Available online: https:/ /www.suerf.org/docx/s_903ce9225fca3e988c2af215d4e544d3_143_ suerf.pdf (accessed on 23 December 2018).

43. Appadurai, A. Disjuncture and Difference in the Global Cultural Economy. Theory Cult. Soc. 1990, 7, $295-310$. [CrossRef]

44. Brundtland, G.H. Our Common Future; Oxford University Press: Oxford, UK, 1987.

45. Perez, C. Unleashing a golden age after the financial collapse: Drawing lessons from history. Environ. Innov. Soc. Transit. 2013, 6, 9-23. [CrossRef]

46. Merton, R.C.; Bodie, Z. Design of Financial Systems: Towards a Synthesis of Function and Structure. J. Invest. Manag. 2005, 3, 1-23. [CrossRef]

47. Ross, S.A. Neoclassical Finance; Princeton University Press: Princeton, NJ, USA, 2004.

48. Shleifer, A. Inefficient Markets: An Introduction to Behavioral Finance; Oxford University Press: Oxford, UK, 2000.

49. Wójcik, D.; Kreston, N.; Mcgill, S. Freshwater, saltwater and deepwater: Efficient market hypothesis versus behavioural finance. J. Econ. Geogr. 2013, 13, 257-277. [CrossRef]

50. Knox-Hayes, J. The Cultures of Markets; Oxford University Press: Oxford, UK, 2016.

51. Hall, S.; Appleyard, L. "City of London, City of Learning"? Placing business education within the geographies of finance. J. Econ. Geogr. 2009, 9, 597-617. [CrossRef]

52. Wójcik, D. The dark side of NY-LON: Financial centres and the global financial crisis. Urban Stud. 2013, 50, 1-16. [CrossRef]

53. Bassens, D.; Derudder, B.; Witlox, F. Searching for the Mecca of finance: Islamic financial services and the world city network. Area 2010, 42, 35-46. [CrossRef]

54. Dörry, S. Regualtory spaces in global finance. In Handbook on the Geographies of Money and Finance; Martin, R., Pollard, J., Eds.; Edward Elgar Publishing: Cheltenham, UK; Northhanmpton, MA, USA, 2017; pp. 415-433.

55. Engelen, E.; Grote, M.H. Stock exchange virtualisation and the decline of second-tier financial centres-the cases of Amsterdam and Frankfurt. J. Econ. Geogr. 2009, 9, 679-696. [CrossRef]

56. Haberly, D.; MacDonald-Korth, D.; Urban, M.A.; Wójcik, D. Asset Management as a Digital Platform Industry: A Global Financial Network Perspective. 2018. Available online: http:/ /dx.doi.org/10.2139/ssrn.3288514 (accessed on 22 February 2019).

57. Barkemeyer, R.; Holt, D.; Preuss, L.; Tsang, S. What happened to the "development" in sustainable development? Business guidelines two decades after Brundtland. Sustain. Dev. 2014, 22, 15-32. [CrossRef]

58. Hunt, C.; Weber, O.; Dordi, T. A comparative analysis of the anti-Apartheid and fossil fuel divestment campaigns. J. Sustain. Financ. Invest. 2017, 7, 64-81. [CrossRef]

59. Muñoz-Torres, M.J.; Fernández-Izquierdo, M.Á.; Rivera-Lirio, J.M.; Escrig-Olmedo, E. Can environmental, social, and governance rating agencies favor business models that promote a more sustainable development? Corp. Soc. Responsib. Environ. Manag. 2018, 1-14. [CrossRef]

60. Ghisellini, P.; Cialani, C.; Ulgiati, S. A review on circular economy: The expected transition to a balanced interplay of environmental and economic systems. J. Clean. Prod. 2016, 114, 11-32. [CrossRef]

61. Clark, G.L.; Monk, A.H.B. The legitimacy and governance of Norway's sovereign wealth fund: The ethics of global investment. Environ. Plan. A 2010, 42, 1723-1738. [CrossRef]

62. The Tobacco Atlas. Consumption. 2016. Available online: https://tobaccoatlas.org/topic/consumption/ (accessed on 23 December 2018). 
63. Ministry of Finance. Two Companies Excluded from the Fund's Investment Universe 2011. Available online: https: / www.regjeringen.no/en/aktuelt/government-pension-fund-global-two-compa/id665637/ (accessed on 23 December 2018).

64. Ministry of Finance. Two Companies-Wal-Mart and Freeport-Are Being Excluded from the Norwegian Government Pension Fund 2006. Available online: https://www.regjeringen.no/no/aktuelt/twocompanies---wal-mart-and-freeport--- /id104396/ (accessed on 23 December 2018).

65. Rio Tinto. Prospectus Supplement, Filed Pursuant to Rule 424(b)(5) 2009. Available online: https: / / www. sec.gov/Archives/edgar/data/863064/000095012309006627/u06687ae424b5.htm (accessed on 23 December 2018).

66. Rio Tinto. Prospectus Supplement, Filed Pursuant to Rule 424(b)(5) 2012. Available online: https: / / www. sec.gov/Archives/edgar/data/863064/000119312512360748/d393162d424b5.htm (accessed on 23 December 2018).

67. Freeport-McMoRan. Prospectus Supplement, Filed Pursuant to Rule 424(b)(5) 2009. Available online: https:/ / www.sec.gov/Archives/edgar/data/831259/000095013409000990/p13988e424b5.htm (accessed on 23 December 2018).

68. NRG Energy. Prospectus Supplement, Filed Pursuant to Rule 424(b)(3) 2009. Available online: https: / / www.sec.gov/Archives/edgar/data/1013871/000095012309010307/y77340e424b3.htm (accessed on 23 December 2018).

69. NRG Energy. Prospectus Supplement, Filed Pursuant to Rule 424(b)(3) 2014. Available online: https: / / www.sec.gov/Archives/edgar/data/1013871/000104746914003097/a2219367z424b3.htm (accessed on 23 December 2018).

70. U.S. House of Representatives Committee on Energy and Commerce. A Review of EPA's Regulatory Activity During the Obama Administration: Energy and Industrial Sectors 2016. Available online: http: / / www.reginfo.gov/public/jsp/EO/eoDashboard.jsp. (accessed on 23 December 2018).

71. CNN Politics. EPA Rolls Back Obama-Era Coal Pollution Rules as Trump Heads to West Virginia 2018. Available online: https:/ / edition.cnn.com/2018/08/21/politics/epa-climate-power-plants-trump-westvirginia/index.html (accessed on 23 December 2018).

72. Ministry of Finance. Mining Company Excluded from the Government Pension Fund-Global Due to Contribution to Serious Environmental Damage 2009. Available online: https:/ / www.regjeringen.no/en/ aktuelt/mining-company-excluded-from-the-governm/id543107/ (accessed on 23 December 2018).

73. Barrick Gold. Prospectus Supplement, Filed Pursuant to Rule 424(b)(5) 2008. Available online: https: / / www. sec.gov/Archives/edgar/data/1435942/000119312508191748/d424b5.htm (accessed on 23 December 2018).

74. Human Rights Watch. Wal-Mart's Violation of US Workers' Right to Freedom of Association 2007. Available online: https: / / www.hrw.org/report/2007/04/30/discounting-rights/wal-marts-violation-us-workersright-freedom-association (accessed on 23 December 2018).

75. Urwin, R. Pension Funds as Universal Owners: Opportunity Beckons and Leadership Calls. Rotman Int. J. Pension Manag. 2011, 4, 26-33. Available online: https:/ / ssrn.com/abstract=1829271 (accessed on 20 March 2019).

76. Financial Times. Norway Wealth Fund Proposes End to Oil and Gas Investment 2017. Available online: https:/ / www.ft.com/content/611c2e9e-cad9-11e7-aa33-c63fdc9b8c6c (accessed on 23 December 2018).

77. Financial Times. Norway Wealth Fund Should Keep Oil Stocks, Says Report 2018. Available online: https: / www.ft.com/content/73928966-a773-11e8-926a-7342fe5e173f (accessed on 23 December 2018).

78. UNPRI. Shifting Perceptions: ESG, Credit Risk and Ratings. 2017. Available online: https://www.unpri. org / download?ac=256 (accessed on 21 February 2019).

(C) 2019 by the authors. Licensee MDPI, Basel, Switzerland. This article is an open access article distributed under the terms and conditions of the Creative Commons Attribution (CC BY) license (http:/ / creativecommons.org/licenses/by/4.0/). 